\begin{tabular}{|l|l|l||}
\hline \multicolumn{2}{|c|}{ PublisherInfo } \\
\hline \hline PublisherName & $:$ & BioMed Central \\
\hline \hline PublisherLocation & $:$ & London \\
\hline \hline PublisherImprintName & $:$ & BioMed Central \\
\hline \hline
\end{tabular}

\title{
Martha Chase dies
}

\begin{tabular}{|l|c|l||}
\hline \multicolumn{2}{|c|}{ ArticleInfo } \\
\hline \hline ArticleID & $:$ & 4830 \\
\hline \hline ArticleDOI & $:$ & $10.1186 /$ gb-spotlight-20030820-01 \\
\hline \hline ArticleCitationID & $:$ & spotlight-20030820-01 \\
\hline \hline ArticleSequenceNumber & $:$ & 182 \\
\hline \hline ArticleCategory & $:$ & Research news \\
\hline ArticleFirstPage & $:$ & 1 \\
\hline \hline ArticleLastPage & $:$ & 4 \\
\hline \hline & & RegistrationDate : 2003-8-20 \\
\hline ArticleHistory & $:$ & OnlineDate \\
\hline \hline ArticleCopyright & $:$ & BioMed Central Ltd2003-8-20 \\
\hline \hline ArticleGrants & $:$ & \\
\hline \hline ArticleContext & $:$ & 130594411 \\
\hline \hline
\end{tabular}


Email: millydawson@alum.wellesley.edu

Martha Chase, renowned for her part in the pivotal "blender experiment," which firmly established DNA as the substance that transmits genetic information, died of pneumonia on August 8 in Lorain, Ohio. She was 75.

In 1952, Chase participated in what came to be known as the Hershey-Chase experiment in her capacity as a laboratory assistant to Alfred D. Hershey. He won a Nobel Prize for his insights into the nature of viruses in 1969, along with Max Delbrück and Salvador Luria.

Peter Sherwood, a spokesman for Cold Spring Harbor Laboratory, where the work took place, described the Hershey-Chase study as "one of the most simple and elegant experiments in the early days of the emerging field of molecular biology."

"Her name would always be associated with that experiment, so she is some sort of monument," said her longtime friend Waclaw Szybalski, who met her when he joined Cold Spring Harbor Laboratory in 1951 and who is now a professor of oncology at the University of Wisconsin-Madison.

Szybalski attended the first staff presentation of the Hershey-Chase experiment and was so impressed that he invited Chase for dinner and dancing the same evening. "I had an impression that she did not realize what an important piece of work that she did, but I think that I convinced her that evening," he said. "Before, she was thinking that she was just an underpaid technician."

In fact, said Szybalski, "Experimentally, she contributed very much. The laboratory of Alfred Hershey was very unusual. At that time there were just the two of them, and when you entered the laboratory there was absolute silence and just $\mathrm{Al}$ directing the experiments by pointing with his finger to Martha, always with a minimum of words. She was perfectly fitted to work with Hershey."

Martha Chase went to work in Hershey's lab at Cold Spring Harbor in 1950, having recently graduated from the College of Wooster in Ohio. In the early 1950s, research on bacteriophages - proteinshrouded DNA viruses that infect bacteria - laid the foundationfor the field of molecular biology. Leading researchers believed that by studying how a single "phage" multiplies within a host bacterium, they were essentially studying stripped-down genes in action.

A key question revolved around which element of the bacteriophage conveyed the genetic information - the protein coat or the DNA within. An experiment done at the Rockefeller Institute in 1944 by Avery, MacLeod, and McCarty had pointed to DNA, but it was the Hershey-Chase experiment that helped to convince the world.

Hershey and Chase added marked bacteriophages to a fresh bacterial culture, allowing the phages to infect the bacteria by injecting their genetic material into the host cell. But then at the crucial moment, they whirled the bacteria in a Waring Blendor, which Hershey had determined produced just the right shearing force to tear the phage particles from the bacterial walls without rupturing the bacteria. Upon examining the bacteria, Hershey and Chase found that only phage DNA, and no detectable protein, had been inserted into the bacteria, confirming the 1944 findings of Avery's group. 
Norton Zinder, a professor of molecular genetics at Rockefeller University, has noted that this experiment "supported the role of DNA [as opposed to protein] and... helped to stimulate Watson and Crick to go on to reveal the structure" of DNA. James Watson said as much himself in a 1997 memoriam, writing that "the Hershey-Chase experiment had a much broader impact than most confirmatory announcements and made me ever more certain that finding the three-dimensional structure of DNA was biology's next important objective. The finding of the double helix by Francis Crick and me came only 11 months after my receipt of a long Hershey letter describing his blender experiment results."

In 1953, Martha Chase left Cold Spring Harbor to work first at the Oak Ridge National Laboratory and then at the University of Rochester. Each summer, though, she returned to Cold Spring Harbor for annual gatherings of the highly respected Phage Group. In 1959, she began work on her PhD at the University of Southern California, earning the degree in 1964. In the late 1950s in California, she had met and married a fellow scientist, Richard Epstein, but they soon divorced.

Chase suffered several other personal setbacks, including a job loss, in the late 1960s, a period that saw the end of her scientific career. Later, she experienced decades of dementia, with long-term but no short-term memory. Szybalski remembered his friend as "a remarkable but tragic person."

Chase, who was born and raised in Cleveland Heights, Ohio, is survived by her sister Ruth Daziel of Milford, Conn. Martha Chase liked to travel and visited many of the national parks, Daziel recalled. "She especially loved going out in the desert after a rain when the flowers were blooming." Chase also enjoyed photography, sewing, and knitting. "The harder the pattern the better she liked it," said Daziel. "All the fancy knitting stitches, like those for argyle socks, were self-taught. She was always interested in anything that was a challenge."

\section{References}

1. Diagram of Hershey-Chase blender experiment, [http://osulibrary.orst.edu/specialcollections/coll/ pauling/dna/pictures/hersheychase-experiment.html]

2. Martha Chase, [http://osulibrary.orst.edu/specialcollections/coll/pauling/dna/people/chase.html]

3. Alfred D. Hershey, [http://www.cshl.edu/History/hershey.html] 
4. Peterson RE: Al's pals reminisce American Scientist, January-February 2001., [http://www.americanscientist.org/template/BookReviewTypeDetail/assetid/ 14294;jsessionid=aaa6YOeEW208kv]

5. Can Matter Store Active Information? Landmarks in the History of Genetics, [http://cogweb.ucla.edu/ep/DNA_history.html]

6. Oswald Avery, [http://osulibrary.orst.edu/specialcollections/coll/pauling/dna/people/avery.html]

7. Watson JD: Alfred Day Hershey 1908-1997 Cold Spring Harbor Laboratory Annual Report 1997, November 10, 1997., [http://www.cshl.edu/AnnualReport/hershey.html]

8. The Phage Group, [http://www.cshl.edu/History/phagegroup.html] 